\title{
Vertical boundary mixing events during stratification govern heat and nutrient dynamics in windy tropical lakes with high water-level fluctuations: a long-term (2001-2018) study.
}

\author{
Martín Merino-Ibarra ${ }^{1 *}$, Jorge A. Ramírez-Zierold ${ }^{2}$, Patricia M. Valdespino-Castillo ${ }^{3}$, F. Sergio Cas- \\ tillo-Sandoval ${ }^{1}$, Andrea P. Guzmán-Arias ${ }^{3}$, Mariel Barjau-Aguilar ${ }^{3}$, Emiliano Monroy-Ríos $^{3}$, Luz M. \\ López- Gómez ${ }^{3}$, Arantxa Sacristán-Ramírez ${ }^{3,4}$, José G. Quintanilla-Terminel ${ }^{3}$, Roberto González-De \\ Zayas $^{5}$, Jorge Jimenez-Contreras ${ }^{6}$, María E. Valeriano-Riveros ${ }^{2}$, Gloria Vilaclara-Fatjó ${ }^{6}$ and Salva- \\ dor Sánchez-Carrillo ${ }^{7}$
}

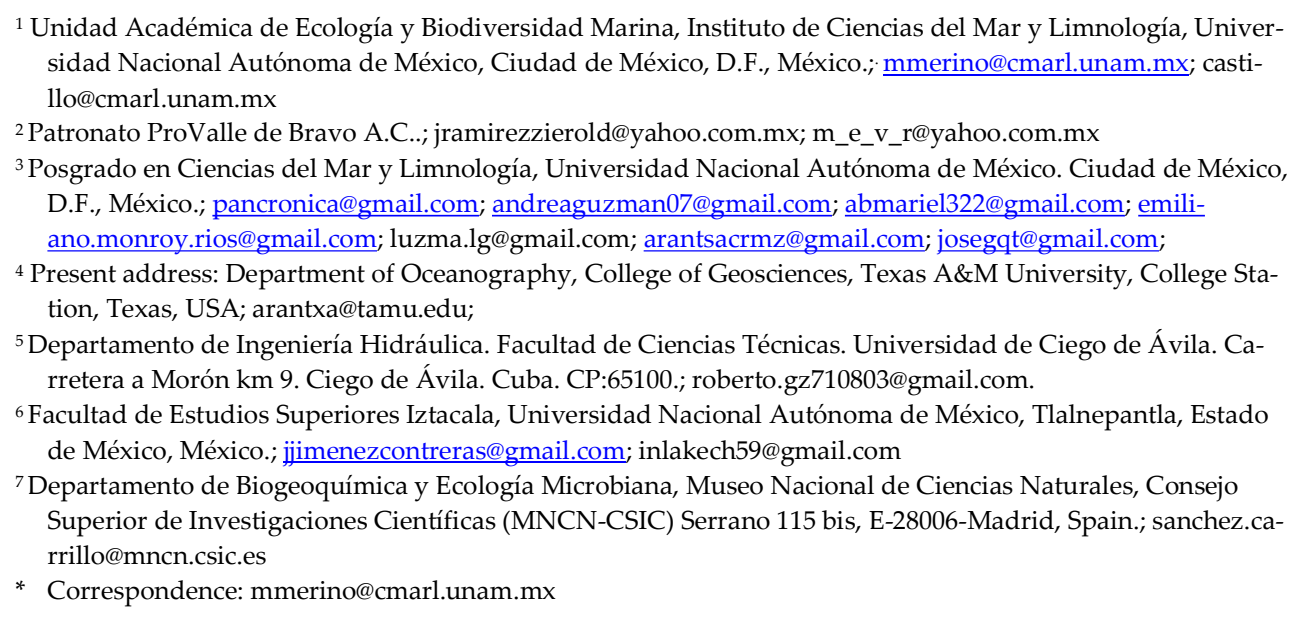

\begin{abstract}
Physical processes play important roles in controlling eutrophication and oligotrophication. In stratified lakes, internal waves can cause vertical transport of heat and nutrients without breaking the stratification, through boundary mixing events. Such is the case in tropical Valle de Bravo (VB) lake, where strong diurnal winds drive internal waves, boundary mixing and hypolimnetic warming during stratification periods. We monitored VB during 18 years (2001-2018) when important water-level fluctuations (WLF) occurred, affecting mixing and nutrient flux. Mean hypolimnetic temperature increase $\left(0.06-1.04^{\circ} \mathrm{C} \mathrm{month}^{-1}\right)$ occurred in all the stratifications monitored. We analyzed temperature distributions and modeled the hypolimnion heat budget to assess vertical mixing between layers $\left(26,618-140,526 \mathrm{~m}^{-3} \mathrm{~h}^{-1}\right)$, vertical diffusivity coefficient $\mathrm{Kz}\left(6.2 \times 10^{-7}-3.3 \times 10^{-6}\right.$ $\left.\mathrm{m}^{2} \mathrm{~s}^{-1}\right)$ and vertical nutrient entrainment to epilimnion on monthly scale. Stability also varied as a function of WLF. Nutrient flux to the epilimnion ranged $0.36-5.99 \mathrm{mg} \mathrm{m}^{-2} \mathrm{~d}^{-1}$ for soluble reactive phosphorus (SRP) and 5.8-97.1 $\mathrm{mg} \mathrm{m}^{-2} \mathrm{~d}^{-1}$ for dissolved inorganic nitrogen (DIN). During low waterlevel years, vertical nutrient fluxes increase and can account for up to $>40 \%$ of the total external nutrients load to the lake. Vertical mixing changes related to WLF affect nutrient recycling, their flux to sediments, ecosystemic metabolic balance and planktonic composition of VB.
\end{abstract}

Keywords: eutrophication; water management; hypolimnetic warming; boundary mixing; mixing events; internal waves; long-term series; Valle de Bravo; biogeochemistry; nutrient flux

\section{Introduction}

Understanding mechanisms that control eutrophication and oligotrophication is an issue that involves fascinating theoretical and applied possibilities. The vertical exchange 
between the warm surface layer (epilimnion) and the colder hypolimnion below the thermocline boundary in stratified systems is an understudied critical process that may affect the nutrient dynamics and, consequently, their trophic condition [1]. In lakes characterized by stable stratification, vertical transport of dissolved materials is generally restricted by the metalimnetic barrier. Therefore, in stratified eutrophic lakes, primary producers inhabiting the epilimnion are often limited by the low availability of dissolved nutrients, while in the hypolimnion, concentrations of these elements can be much higher due to the microbial transformation of settling organic material and to their release from the bottom sediments [e.g.2]. Thus, any physical mechanism responsible for significant cross-metalimnetic upward mass transport will be important in controlling the system's productivity and its trophic condition.

External loading and deep-water entrainment are usually the two dominant sources of nutrients to lakes at an annual time scale, yet their relative importance during the period of stratification and low nutrient availability is under discussion [3]. Because crossing the metalimnetic density barrier requires energy, entrainment -the transport of nutrients from the deep water- has been considered low or negligible during strong stratification [4]. Recent work, however, suggests that the vertical flux of nutrients across the thermocline may be an important driver of epilimnetic metabolism in some stratified lakes [5]. In these cases, the energy required has often been shown to come from processes such as wind mixing and shear production within boundary layers of the lake [6]. Intense periodical winds can drive internal waves, which can cause increased dissipation of turbulent kinetic energy both at the periphery and the center of the lake [7]. A recent study [8] reports that the synchronization of internal waves can even provoke enhanced shear in the hypolimnion and vertical diffusivity $(\mathrm{Kz})$ reaching up to $10^{-4} \mathrm{~m}^{2} \mathrm{~s}^{-1}$. Nevertheless, processes driving the enhancement of boundary mixing events and hypolimnetic entrainment are still understudied, and even more seldom approached in tropical lakes [9,10].

This kind of processes likely occur in Valle de Bravo (VB) [11], a deep monomictic tropical lake in Central Mexico, which is daily swept by strong (7.4-16.5 $\mathrm{m} \mathrm{s}^{-1}$ ) diurnal (12:00-19:00 h) winds. Important vertical diurnal displacements of the thermocline at the extremes of the lake reveal the internal waves driven by diel winds in VB [12]. Through the interaction of the thermocline with the bottom and margins of the lake, these internal waves drive daily boundary mixing events in VB during the stratification period, when an hypolimnetic warming occurs [11]. Regular, long-term monitoring of VB has shown that this hypolimnetic warming occurs during every seasonal stratification period. While boundary mixing events are not strong enough to break the stratification in VB, their cumulative effect drives this observed increase of the hypolimnetic temperature, which varies depending on the intensity and frequency of the mixing events at VB $[11,13,14]$.

Additionally, because VB is a reservoir used for water supply, it exhibits important water level fluctuations (WLF), as a result of the variations on water demand and on rainfall in its basin [15]. This is a relevant characteristic of VB because it is well known that high WLF can affect multiple processes in water bodies $[9,13,16]$. In particular, long-term studies on the metabolic balance of the lake have shown that it varies as a function of WLF, and suggest that WLF probably intensify the boundary mixing events that take place in $\mathrm{VB}[14]$.

In fact, it is well known that mixing processes and their variability can significantly affect multiple aspects, including nutrient availability and budgets[5,7,9,11,15], ecosystem metabolism [5,14] as well as plankton composition and dominance $[13,17]$ in all kinds of water bodies. In VB there are, additionally, other important management issues -such as toxic cyanobacterial blooms- that challenge its value and use as a touristic hot spot [11], which are also affected by these mixing processes and their variability associated to WLF. Indeed, this has been outlined as a broadly found issue by [9], who stressed that the response of aquatic ecosystems, particularly deep lakes, to WLF is an under-studied field of crucial importance to the management of water resources. 
Because important WLF have been occurring in VB in the past two decades, their study on the long-term can contribute to the understanding of their effects on mixing and biogeochemical processes and to better manage deep monomictic lakes and reservoirs in order to cope with their eutrophication, which is an urgent management issue [18]. We have been monitoring this lake for over 18 years, and here we report on the variability of temperature distributions in the water column of this lake with a strong diurnal wind regime, and use the hypolimnetic temperature increase rates observed during each of the stratification periods to calculate the water mass mixing between layers of each stratification cycle. These calculations yield estimates of the magnitude of vertical mixing, the coefficient of vertical eddy diffusivity $(\mathrm{Kz})$ and the vertical nutrient entrainment into the epilimnetic zone. The temporal variability of these fluxes is analyzed to assess the effects of water level fluctuations (WLF) on the intensity of this water mixing and nutrient entrainment, which in turn have important ecological effects and implications that should be considered for the urgent and adequate management of tropical lakes and reservoirs [18].

\section{Materials and Methods}

\subsection{Study Area}

Valle de Bravo (VB) is the biggest of seven reservoirs that form the Cutzamala System, which provides $30 \%$ of the drinking water supply to the Mexico City Metropolitan Area and other cities. Nevertheless, because of its depth, VB behaves as a monomictic lake [11]. This high-altitude $(1,830 \mathrm{~m}$ a.s.l. at its maximum water level) tropical lake in Central Mexico $\left(19^{\circ} 21^{\prime} 30^{\prime} \mathrm{N}\right.$; $\left.100^{\circ} 11^{\prime} 00^{\prime \prime} \mathrm{W}\right)$ receives water from a $547 \mathrm{~km}^{2}$ watershed through 4 main rivers (Amanalco, Molino, González y Carrizal) and at least three sewage outlets, including Tizates, a former river [15]. The lake's surface is $18.6 \mathrm{~km}^{2}$, its mean depth 21.1 $\mathrm{m}$, and its maximum depth is $38.6 \mathrm{~m}$. As previously mentioned, this deep lake is characterized by strong diurnal winds that blow along its two arms, of which the longer has a $6.9 \mathrm{~km}$ length (Figure 1). The wind at VB exhibits a regular diurnal pattern (12:00-19:00 h) blowing from the reservoir's dam (WNW) into the valley arms (SSE). Diurnal wind speed averages $5.5 \mathrm{~m} \mathrm{~s}^{-1}$ and frequently reaches over $10 \mathrm{~m} \mathrm{~s}^{-1}[11]$.

Limnologically, VB exhibits a warm-monomictic thermal regime, similar to other water bodies of the Mexican tropical highlands, except for the occurrence of a continuous increase of its hypolimnetic temperature during the stratification period [11]. In contrast, no hypolimnetic temperature increase has been observed in any other water bodies of the Mexican tropical highlands [19]. 


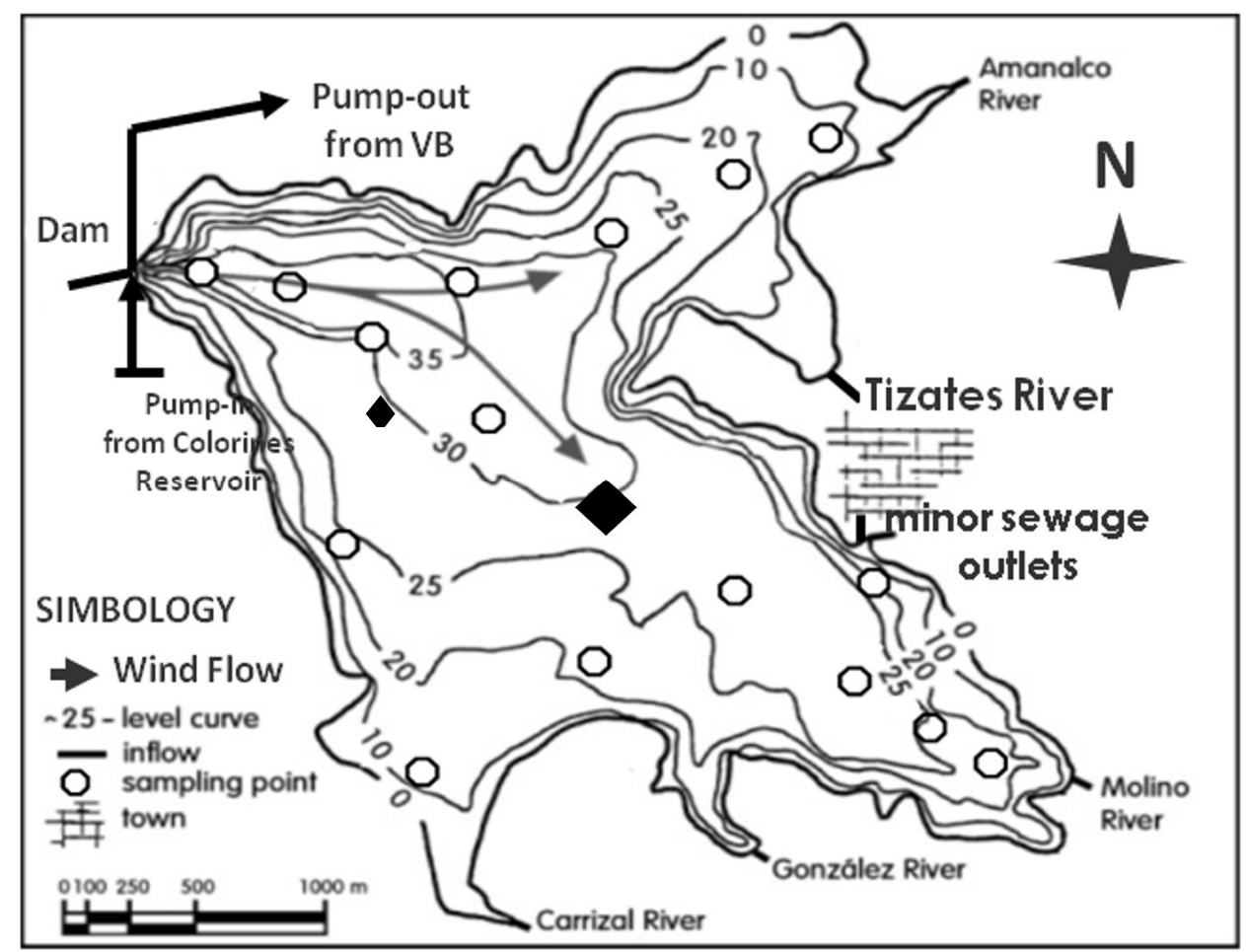

Figure 1. Bathymetric map of Valle de Bravo (VB) Lake (after [15]) showing sampling stations, main inputs (rivers and sewages) and water withdrawal route. Central station sampled throughout the studied period indicated by $\bullet$. Depth contours in $\mathrm{m}$ below the maximum level of the lake. Daily wind pathways over both arms are also indicated $(\rightarrow)$.

\subsection{Long-term monitoring of $V B$}

VB monitoring was performed monthly at up to seventeen sampling stations distributed throughout the water body and along the wind axis (Figure 1). During the initial years of the monitoring (2001-2003), all the stations shown in Figure 1 were sampled to identify and include any spatial variations that could happen. However, as the existence of horizontal homogeneity in VB was confirmed [11,20], the number of stations was reduced, initially to 5 stations, and from September 2007 on to a single sampling station at the center of the lake, to extend the viability of a the long-term monitoring that has proceeded since then. The reservoir's water level during each sampling date was obtained from the government official reports, and the area of the lake at different depths was obtained from the bathymetry reported by [11].

Temperature and dissolved oxygen (DO) were measured at $1 \mathrm{~m}$ vertical intervals using an Hydrolab DS4/SVR4 (From February 2001-September 2004) or a Yellow Spring Instruments (YSI) field probe (October 2004-January 2019), which were previously intercalibrated. Water samples were collected with a 1.51 Uwitec sampler at regular vertical intervals $(0,1,2,4,8,12,17,20,24,28$ and $32 \mathrm{~m}$, when possible) all the way down to the bottom of the lake. Subsamples for nutrients [dissolved inorganic nitrogen (DIN) $=\left[\mathrm{NH}_{4}{ }^{+}+\mathrm{NO}_{2}{ }^{-}\right.$ $+\mathrm{NO}_{3}{ }^{-}$, and soluble reactive phosphorus (SRP)] analysis were held in polypropylene containers after filtration with 0.45 and $0.22 \mu \mathrm{m}$ (Millipore ${ }^{\mathrm{TM}}$ type HA) nitrocellulose membranes, and kept frozen until their analysis (within 24 to $48 \mathrm{~h}$ ) in a Skalar segmented-flow continuous auto-analyzer; using the methods and circuits suggested by [21].

\subsection{Vertical mixing model and calculations}

Our approach is based on the increasing evidence $[6,22-24]$ that turbulence generated by internal waves breaking in boundary mixing events can transport nutrients and gases vertically through the metalimnion in systems where a source of external energy, such as 
wind, drives these processes, as summarized in Figure 2. In VB, these mixing events drive a continuous warming of the hypolimnion than continues along all of the stratification period.

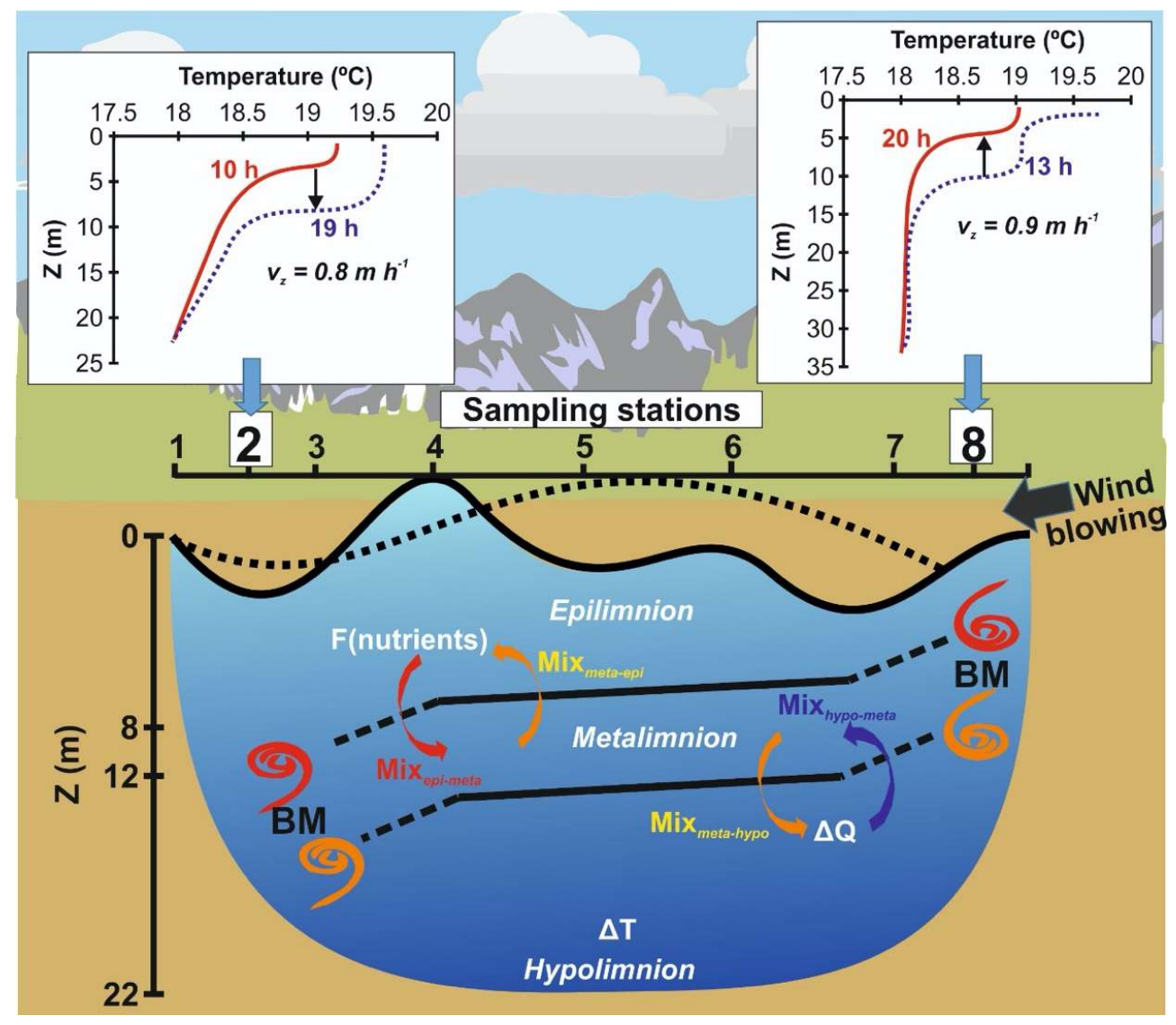

Figure 2. Observed daily thermocline oscillation driven by diurnal wind forcing in VB (top diagrams, taken from [12]), and conceptual mixing model processes considered (see section 2.4 for further explanation).

\subsection{Hypolimnetic heat balance and calculation of vertical water mixing}

There are not any geothermal or groundwater sources of heat in VB that could be driving the warming of the hypolimnion [11]. The high turbidity of the reservoir watermean Secchi depth is of only $1.4 \mathrm{~m}$ (stratification averages range: 1.15-1.65) during the stratification periods [14]- constrains the penetration of solar radiation heating to the first few meters of the epilimnion. Therefore, the hypolimnetic thermal increase we found was entirely attributed to vertical mixing events. We used the simplest model possible, considering the three distinct water layers in a monomictic lake: the warm epilimnion, metalimnion or thermocline layer, and the colder hypolimnion (Figure 2). As there are no other heat inputs to the hypolimnion of $\mathrm{VB}$, it is reasonable to trace back the vertical mixing between from the metalimnion to the hypolimnion, Mix meta-hypo, from the observed hypolimnetic temperature increases. This was done through a heat balance of the hypolimnion (2), taking into account both the heat exchange due to: a) vertical mixing of water

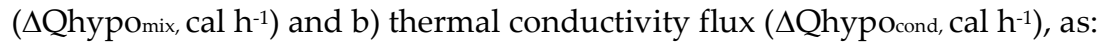

$$
\Delta \text { Qhypotot }=\Delta \text { Qhypomix }+\Delta \text { Qhypocond }
$$


Total heating of the hypolimnion, $\Delta$ Qhypotot, was calculated for each period between samplings $\left(\Delta \mathrm{t}\right.$, days), using the observed temperature increase $\left(\Delta \mathrm{T}_{\text {hypo }}{ }^{\circ} \mathrm{C}\right)$, the calorific capacity of water, $\left(\mathrm{c}, \mathrm{cal} \mathrm{g}^{-1}{ }^{\circ} \mathrm{C}^{-1}\right)$, the volume of the hypolimnion $\left(\mathrm{V}_{\text {hypo, }} \mathrm{m}^{3}\right)$ and the mean hypolimnetic density ( $\rho$ hypo, $\left.\mathrm{g} \mathrm{cm}^{-3}\right)$, as:

$$
\Delta \text { Qhypotot }=\left(\Delta \text { Thypo }_{\text {c }} / \Delta \mathrm{t}\right)^{*} \mathrm{~V}_{\text {hypo }}{ }^{*} \text { Phypo }
$$

The conductivity heat flux, $\Delta$ Qhypocond, was calculated from the vertical temperature gradient $\left(\Delta \mathrm{T}_{\text {epi-hypo }}\right)$ at the metalimnion-hypolimnion frontier and the water thermal conductivity. Then, the mixing heat exchange was calculated by subtracting the thermal conductivity flux from the total heat exchange (equation 3). In turn, from the obtained heat exchange due to mixing ( $\Delta$ Qhypomix), the volume of water exchanged (Vhypo was calculated as:

$$
\text { MiXmeta-hypo }=\Delta \text { Qhypomix } / \text { Phypo } \mathrm{C}\left(\mathrm{T}_{\text {epi }}-\mathrm{T}_{\text {hypo }}\right)
$$

Where Mixmeta-hypo $\left(\mathrm{m}^{3} \mathrm{~h}^{-1}\right), \Delta$ Qhypomix (heat exchange due to water mixing; $\mathrm{cal} \mathrm{h}^{-1}$ ),

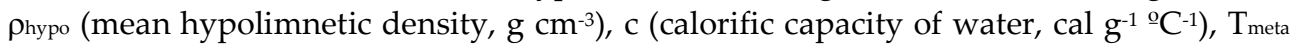
(mean metalimnetic temperature, ${ }^{\circ} \mathrm{C}$ ) and Thyp (mean hypolimnetic temperature, ${ }^{\circ} \mathrm{C}$ ).

The vertical diffusivity coefficient, $\mathrm{Kz}\left(\mathrm{m}^{2} \mathrm{~s}^{-1}\right) \operatorname{sensu}[6,8]$ was calculated dividing the vertical water flow (Mixmeta-hypo) by the exchange area at the depth of the base of the metalimnion and the top of the hypolimnion, which we estimated at $1.2 * 10^{6} \mathrm{~m}^{2}$.

The stability of stratification (S) was also calculated for each sampling date through the Schmidt index [25], integrating from the surface to the maximum depth:

$$
\begin{gathered}
S=g / A_{o} \Sigma\left(\rho_{z}-\rho_{m}\right)\left(z-z_{g}\right) A_{z} \Delta z \\
\text { where: } \rho_{m}=1 / V \int A_{z} \rho_{z} d z
\end{gathered}
$$

Stability is expressed in work units per surface lake area because it represents the amount of work that would be required to mix the lake into an isothermal state. It describes how much the center of mass of the lake has been lowered by the stratification process.

\subsection{Calculation of vertical nutrient fluxes}

To assess the vertical flux of nutrients toward the epilimnion, estimates of both the metalimnetic concentration of nutrients and of the vertical rate of metalimnetic water mixed into the epilimnion (Mixmeta-epi) are needed.

Because, in spite of the hypolimnetic warming, the thermal structure did not change notoriously in VB between samplings, and the lake remained stratified during the spring to autumn months, it is reasonable to assume a steady-state condition of vertical mixing, in which vertical water exchange between the epilimnion and the metalimnion is similar to vertical water exchange between this thermocline layer and the hypolimnion in both directions (Figure 2, Equation 6).

$$
\text { Mixepi-meta } \simeq \text { Mixmeta-hypo } \simeq \text { Mixhypo-meta } \simeq \text { Mixmeta-epi }
$$

We therefore used the calculated Mixmeta-hypo to estimate Mixmeta-epi, the vertical water flux responsible for transporting nutrients to the epilimnion. So, the nutrient entrainment, or flux to the epilimnion ( $\mathrm{F}$ (nutrients)), for each period between samplings was calculated as the product of mean nutrient concentration in each layer multiplied by Mixmeta-hypo :

$$
\mathrm{F} \text { (nutrients) }=\text { Mixmeta-hypo. }{ }^{*} \text { [nutrients] }
$$

Where $\mathrm{F}$ (nutrients) is the ascending nutrient flux $\left(\mathrm{kg} \mathrm{h}^{-1}\right)$; Mixmeta-hypo the exchange of water between layers $\left(\mathrm{m}^{3} \mathrm{~h}^{-1}\right)$ and [nutrients] is the mean metalimnetic concentration of SRP, ammonia or DIN $\left(\mathrm{kg} \mathrm{m}^{-3}\right)$. 


\section{Results}

\subsection{Water Level Fluctuations (WLF) in VB during 2001-2018}

A seasonal variation on the water level of the VB was observed during the full study period (Fig. 3a), which followed the seasonal rain variations for the region, where the rainy season is from June to October. These seasonal water level variations were generally of only 4-6 meters, between the lake's capacity (maximum level $1830 \mathrm{~m}$ a.s.l.) at the end of the rainy season and a minimum of 1824 to $1826 \mathrm{~m}$ a.s.l. by the end of the dry season (Fig. 3a). However, the level of the lake varied more drastically during 2005-2013, decreasing over $12 \mathrm{~m}$ below its capacity and remained well below its maximum level for most of the years except for 2010 (Fig. 3a). Three extraordinary minimum water levels were reached in the summers of 2006 (1819.7 m a.s.l.), 2009 (1817.9 m a.s.l.) and 2013 (1818.3 m a.s.1.).

a)

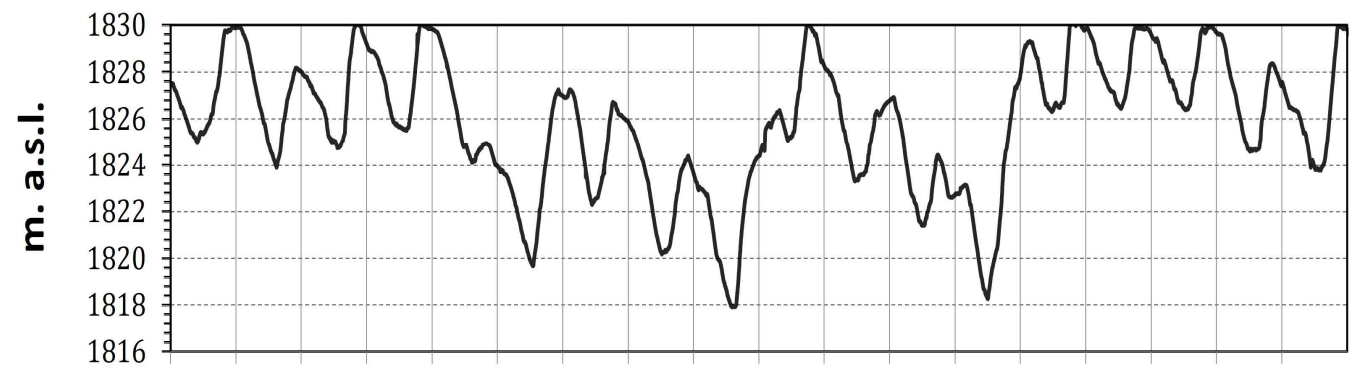

b)

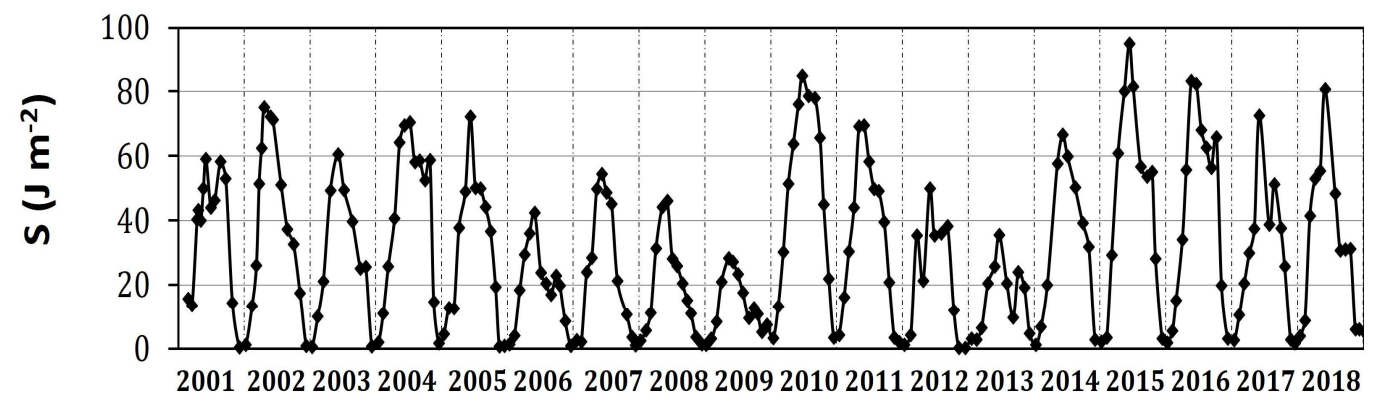

c)

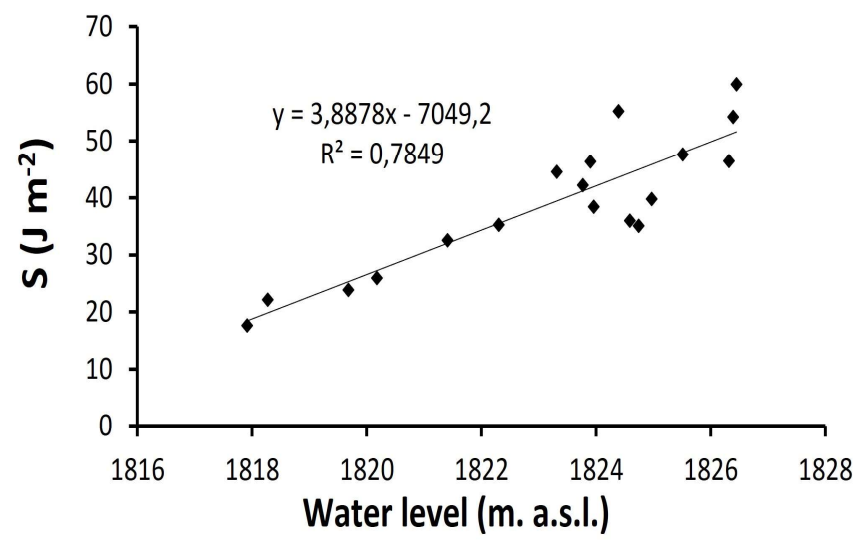

Figure 3. Temporal variations during 2001-2018 in VB of (a) water level (daily resolution),(b) stability of stratification (S), and (c) relationship between mean $\mathrm{S}$ and mean water level over the stratification periods.

\subsection{Thermal regime and stratification}

During 2001-2008, VB behaved every year as a warm monomictic lake with a mean stratification period of $219.8 \pm 30.6$ days. A typical seasonal pattern occurred in the reservoir during the 18 years studied: the maximum surface temperature was reached in June, 
with slight variations (23.0-23.9 C) among years. Circulation began in November and the water column remained homogeneous every winter, at least from December through January. As expected, the stability of the water column also followed a seasonal pattern, reaching high values $\left(>20.0 \mathrm{~J} \mathrm{~m}^{-2}\right)$ during all the stratification periods, and decreasing to zero every year during the mixing periods (Fig. 3b). This seasonal pattern of the stability confirms that stratification was never broken during any of the stratifications of the full 2001-2018 period. Nevertheless, it was also revealed that the maximal stability observed during each of the stratifications diminished signifficantly as the water level decreased (Fig. 3c).

\subsection{Hypolimnetic warming}

The mean temperature of the hypolimnion of VB increased between consecutive samplings during each and every stratification period of the 18 years here reported (Fig. 4a). The rates of temperature increase between consecutive samplings ranged overall 0.0003 $0.04^{\circ} \mathrm{C} \mathrm{d}^{-1}$, while the mean rates for each entire stratification period, as estimated by linear regressions in Figure 4a ranged from $0.009-0.022^{\circ} \mathrm{C} \mathrm{d}^{-1}$, and the maximum mean increases ocurred during the stratifications of $2009\left(0.022^{\circ} \mathrm{C} \mathrm{d}-1\right), 2013\left(0.020^{\circ} \mathrm{C} \mathrm{d}-1\right)$ and 2006 $\left(0.019^{\circ} \mathrm{C} \mathrm{d}-1\right)$. Although linear fits yielded quite high correlation coefficients for all the stratification periods ( $\mathrm{R}^{2}$ ranging from 0.965 to 0.999 ) some of the stratifications showed a sigmoidal trend (e.g. 2016, 2012, 2018, 2005), that could be related to the transitions between stratification and circulation periods.

a)

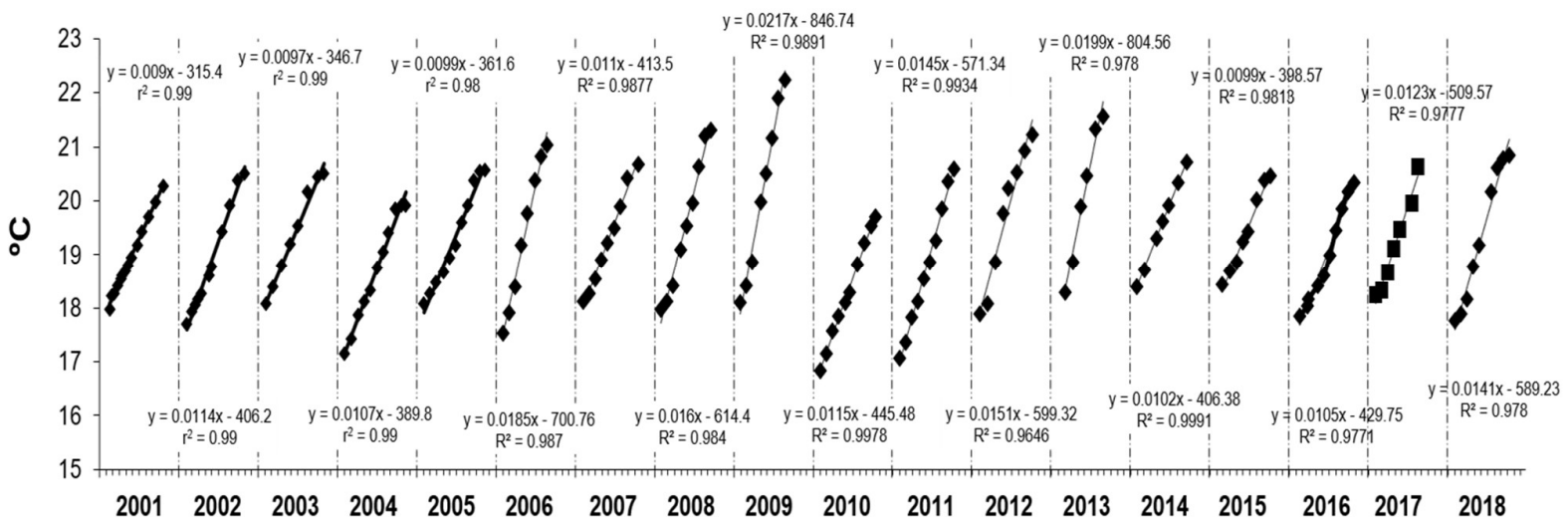

b)

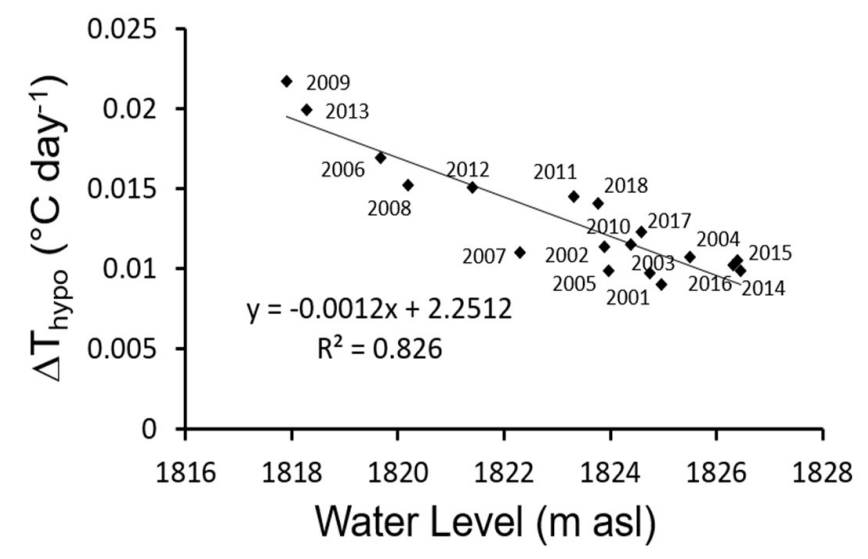

Figure 4. Hypolimnetic water warming and water level relationship in VB: (a) Hypolimnetic temperature variation during each stratification period sampled from 2001 to 2018 [the slopes of the regressions were used to assess the mean warming rate for each of the stratifications] and (b) mean hypolimnetic temperature increase rate during each annual stratification period plotted against the mean water level throughout 2001-2018. 
When the mean thermal increase during the stratification was compared among years, it showed a strong inverse correlation with the mean water level for that year $\left(\mathrm{R}^{2}=0.826\right)$ : the lower the level of the lake, the higher the rate of hypolimnetic warming (Fig. $4 \mathrm{~b}$ ).

\subsection{Mixmeta-hypo, $\mathrm{Kz}$ and nutrient fluxes}

The rate of vertical water mixing (Mixmeta-hypo) ranged from $26,618 \mathrm{~m}^{3} \mathrm{~h}^{-1}$ to $140,526 \mathrm{~m}^{3} \mathrm{~h}^{-1}$ among the stratifications, being lowest in 2015 and highest in 2009 (Table 1). Average vertical mixing during the stratification periods showed an inverse relationship with the mean water level for each year, with a good fit $\left(\mathrm{R}^{2}=0.826\right)$ through a polynomial regression (Fig. 5).

Table 1. Mean vertical water mixing rates $\left(\mathrm{m}^{3} \mathrm{~h}^{-1}\right)$ and mean vertical diffusivity coefficients, $\mathrm{Kz}\left(\mathrm{m}^{2}\right.$ $\left.\mathrm{s}^{-1}\right)$, calculated for VB.

\begin{tabular}{ccc}
\hline $\begin{array}{c}\text { Stratification } \\
\text { Period }\end{array}$ & $\begin{array}{c}\text { Mix meta-hypo } \\
\left(\mathbf{m}^{3} \mathbf{h}^{-1}\right)\end{array}$ & $\begin{array}{c}\mathbf{K z} \\
\left(\mathbf{m}^{\mathbf{2}} \mathbf{s}^{-1}\right)\end{array}$ \\
\hline 2001 & 35,862 & $8.3 \times 10^{-7}$ \\
2002 & 38,480 & $8.9 \times 10^{-7}$ \\
2003 & 44,035 & $1.0 \times 10^{-6}$ \\
2004 & 36,652 & $8.5 \times 10^{-7}$ \\
2005 & 43,567 & $1.0 \times 10^{-6}$ \\
2006 & 70,465 & $1.6 \times 10^{-6}$ \\
2007 & 53,254 & $1.2 \times 10^{-6}$ \\
2008 & 81,774 & $1.9 \times 10^{-6}$ \\
2009 & 140,526 & $3.3 \times 10^{-6}$ \\
2010 & 59,942 & $1.4 \times 10^{-6}$ \\
2011 & 52,963 & $1.2 \times 10^{-6}$ \\
2012 & 60,262 & $1.4 \times 10^{-6}$ \\
2013 & 97,856 & $2.3 \times 10^{-6}$ \\
2014 & 34,656 & $8.0 \times 10^{-7}$ \\
2015 & 26,618 & $6.2 \times 10^{-7}$ \\
2016 & 29,678 & $6.9 \times 10^{-7}$ \\
2017 & 53,998 & $1.2 \times 10^{-6}$ \\
2018 & 49,170 & $1.1 \times 10^{-6}$ \\
Mean & 56,098 & $\mathbf{1 . 3 \times 1 0 ^ { - 6 }}$ \\
\hline
\end{tabular}




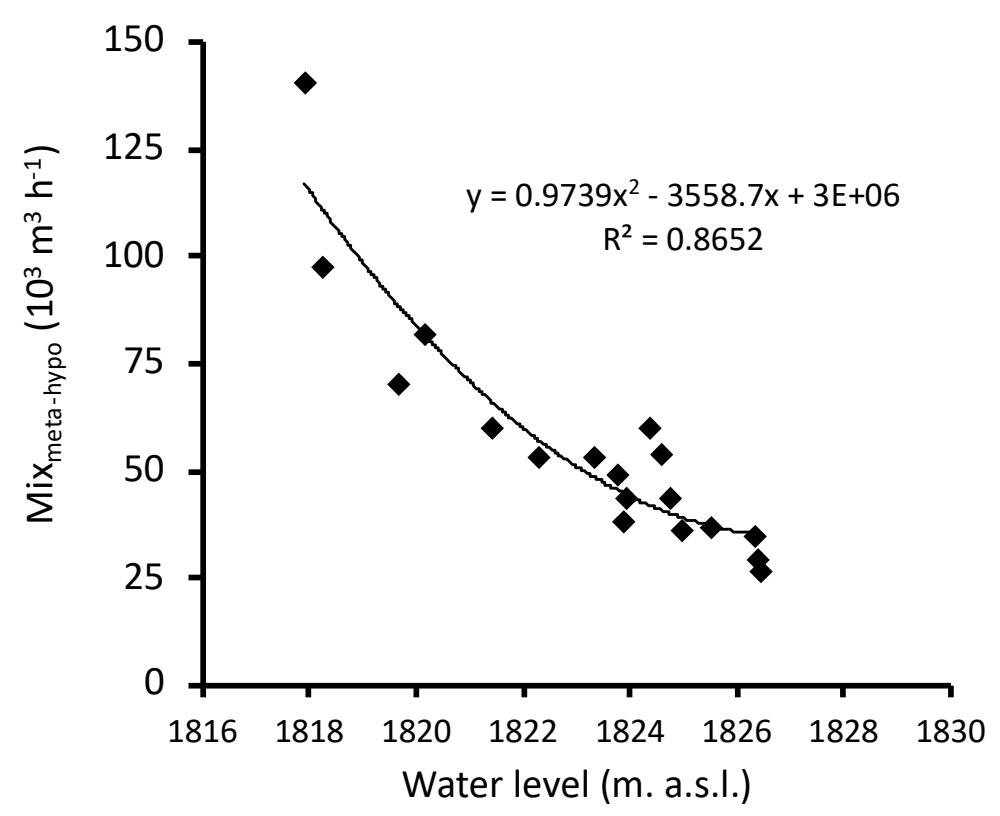

Figure 5. Mean vertical mixing rate (Mixmeta-hypo) plotted against the annual mean water level of VB.

The mean calculated vertical diffusivity coefficients $(\mathrm{Kz})$ followed a similar pattern among years, ranging from a $6.2 \times 10^{-7} \mathrm{~m}^{2} \mathrm{~s}^{-1}$ average during the stratification of 2015 to a mean of $3.3 \times 10^{-6} \mathrm{~m}^{2} \mathrm{~s}^{-1}$ during the stratification of 2009 (Table 1), when the water level was lowest during the full period. On the monthly scale of our calculations, the range of the $\mathrm{Kz}$ values calculated was wider, from as low as $4.0 \times 10^{-8} \mathrm{~m}^{2} \mathrm{~s}^{-1}$ to as high as $1.2 \times 10^{-5} \mathrm{~m}^{2} \mathrm{~s}^{-1}$ (Table 2).

Table 2. Mean and range of the vertical diffusion coefficients, Kz, obtained for VB during the stratification periods of 2001-2018 and a comparison with $\mathrm{Kz}$ reported for other water bodies. The mean and range (in parenthesis) of $\mathrm{Kz}$ values are included. Data are ordered from higher to lower Kz mean values, and the position of VB among other lakes and reservoirs is outlined in bold characters and green shading. When not reported, mean $\mathrm{Kz}$ were calculated from the values available.

\begin{tabular}{|c|c|c|c|}
\hline \multicolumn{2}{|c|}{$\mathbf{K z}$} & \multirow[t]{2}{*}{ Location } & \multirow[t]{2}{*}{ Reference } \\
\hline Mean & (Range) & & \\
\hline $6.2 \times 10^{-6}$ & $\left(4.0 \times 10^{-8}-1.2 \times 10^{-5}\right)$ & VB (monthly integrated) & This paper \\
\hline $1.3 \times 10^{-6}$ & $\left(6.2 \times 10^{-7}-3.3 \times 10^{-6}\right)$ & VB (annual mean) & This paper \\
\hline $5.0 \times 10^{-4}$ & $\left(1.0 \times 10^{-5}-1.0 \times 10^{-3}\right)$ & North Lake, Australia & [26] MacIntyre 1993 \\
\hline $1.0 \times 10^{-4}$ & $\left(8.0 \times 10^{-5}-1.3 \times 10^{-4}\right)$ & Lake Rotowhero, New Zealand & [27] Brookes et al. 2013 \\
\hline $6.5 \times 10^{-5}$ & $\left(2.2 \times 10^{-5}-1.1 \times 10^{-4}\right)$ & Lake Lanao, Philippines & [28] Lewis 1982 \\
\hline $5.1 \times 10^{-5}$ & $\left(1.0 \times 10^{-6}-1.0 \times 10^{-4}\right)$ & Lake Biwa, Japan & [8] Auger et al. 2014 \\
\hline $5.1 \times 10^{-5}$ & $\left(1.0 \times 10^{-6}-1.0 \times 10^{-4}\right)$ & Kranji reservoir, Singapore & [29]Yang et al. 2019 \\
\hline $4.5 \times 10^{-5}$ & $\left(1.0 \times 10^{-6}-9.0 \times 10^{-5}\right)$ & Green Lake, & [30] Stauffer 1987 \\
\hline $4.5 \times 10^{-5}$ & $\left(8.0 \times 10^{-5}-1.0 \times 10^{-5}\right)$ & Lake Kinneret, Israel & [31] Saggio and Imberger 2001 \\
\hline $1.8 \times 10^{-5}$ & $\left(1.6 \times 10^{-5}-2.1 \times 10^{-5}\right)$ & Fitzroy River Barrage, Australia & [32] Bormans et al. 2004 \\
\hline $1.2 \times 10^{-5}$ & & Lake Constance, Germany-Switzerland & [33] Preusse et al. 2010 \\
\hline $6.2 \times 10^{-6}$ & $\left(4.0 \times 10^{-8}-1.2 \times 10^{-5}\right)$ & Valle de Bravo (monthly integrated) & This paper \\
\hline $6.0 \times 10^{-6}$ & $\left(9.0 \times 10^{-6}-1.1 \times 10^{-5}\right)$ & Lake Valencia, Venezuela & [34] Lewis 1983 \\
\hline $6.0 \times 10^{-6}$ & $\left(6.0 \times 10^{-6}-5.0 \times 10^{-5}\right)$ & Lake Mcllwaine, Rhodesia & [35] Robarts \& Ward 1978 \\
\hline $5.0 \times 10^{-6}$ & & Lake Matano, Indonesia & [36] Katsev et al. 2010 \\
\hline $3.4 \times 10^{-6}$ & $\left(1.0 \times 10^{-7}-2.6 \times 10^{-5}\right)$ & Mono Lake, California & [37] Jellison \& Melack 1993 \\
\hline
\end{tabular}




\begin{tabular}{llll}
$2.2 \times 10^{-6}$ & $\left(3.0 \times 10^{-6}-8.0 \times 10^{-5}\right)$ & Lake Alpnach (central Switzerland) & [38] Goudsmith et al. 1997 \\
\hline $\mathbf{1 . 3 \times 1 0 ^ { - 6 }}$ & $\left(\mathbf{6 . 2 \times 1 0 ^ { - 7 } - 3 . 3 \times 1 0 ^ { - 6 } )}\right.$ & Valle de Bravo (annual mean) & This paper \\
$1.3 \times 10^{-6}$ & $\left(2.0 \times 10^{-7}-2.5 \times 10^{-6}\right)$ & Castle Lake, California & [39] Jassby and Powell 1975 \\
$1.0 \times 10^{-6}$ & $\left(1.0 \times 10^{-8}-1.0 \times 10^{-4}\right)$ & Mono Lake, California & [6] MacIntyre et al. 1999 \\
$1.0 \times 10^{-8}$ & & Molecular conductivity & [6] MacIntyre et al. 1999
\end{tabular}

Vertical nutrient fluxes towards the epilimnion also varied inversely with the lake's water level, following a pattern similar to that of Mixmeta-hypo and $\mathrm{Kz}$ (Fig. 6, Table 3). SRP vertical flux to the epilimnion ranged from 0.56 to $5.99 \mathrm{mg} \mathrm{SRP} \mathrm{m}^{-2} \mathrm{~d}^{-1}$ among the different stratification periods and averaged $1.97 \mathrm{mg} \mathrm{SRP} \mathrm{m}^{-2} \mathrm{~d}^{-1}$ for the full 18 years studied. DIN vertical flux to the epilimnion ranged from 5.79 to $97.12 \mathrm{mg}^{\mathrm{DIN} \mathrm{m}} \mathrm{m}^{-2} \mathrm{~d}^{-1}$ among the different stratifications and averaged $30.45 \mathrm{mg}^{\mathrm{DIN} \mathrm{m}} \mathrm{m}^{-2} \mathrm{~d}^{-1}$ for the 18 years studied. Signifficant inverse correlations $\left(R^{2}=0.684\right.$ for SRP and $R^{2}=0.563$ for DIN) were obtained with water level, although -as expected- nutrient fluxes exhibited a higher variability because of the additional variability of nutrient concentration, as can be seen in Figure 6.

Table 3. Mean Nutrient fluxes $\left(\mathrm{mg} \mathrm{m}^{-2} \mathrm{~d}^{-1}\right)$ obtained for VB during the stratification periods of 2001-2018 and during the stratification with the lowest water level. Fluxes reported from other lakes are also included for comparison. Other lakes data are ordered by increasing SRP flux, and the position VB fluxes among these values is outlined in bold characters and green shading.

\begin{tabular}{|c|c|c|c|c|}
\hline SRP & Ammonia & DIN & Lake & Reference \\
\hline 1.97 & 12.3 & 30.5 & Valle de Bravo (mean) & This paper \\
\hline 5.99 & 63.1 & 97.1 & $\begin{array}{l}\text { Valle de Bravo (lowest water } \\
\text { level) }\end{array}$ & This paper \\
\hline 0.10 & & & Lake Fish, Wisconsin, USA & [30] Stauffer 1987 \\
\hline 1.60 & 6.2 & & Lake McIlwaine, Rhodesia & [35] Robarts and Ward 1978 \\
\hline 1.97 & 12.3 & 30.5 & Valle de Bravo (overall mean) & This paper \\
\hline 2.71 & & & Lake Kivu, Africa & [40] Pasche et al 2009 \\
\hline 2.59 & & & Lake Mendota, Wisconsin, USA & [41]Kamarainen et al 2009 \\
\hline$\sim 3.00$ & $\sim 20.0$ & & Lake Malawi/Nyasa, Africa & [42] Hamblin et al. 2003 \\
\hline 3.20 & & & Lakes of Taylor Valley, Antarctica & [43] Edwards and Priscu 1995 \\
\hline 5.50 & & & Lake Green, Wisconsin, USA & [30] Stauffer 1987 \\
\hline 5.99 & 63.1 & 97.1 & $\begin{array}{l}\text { Valle de Bravo (lowest water } \\
\text { level) }\end{array}$ & This paper \\
\hline 15.20 & & & Lake Delavan, Wisconsin, USA & [30] Stauffer 1987 \\
\hline & 39.2 & & Mono Lake, California, USA & [6]MacIntyre et al 1999 \\
\hline
\end{tabular}



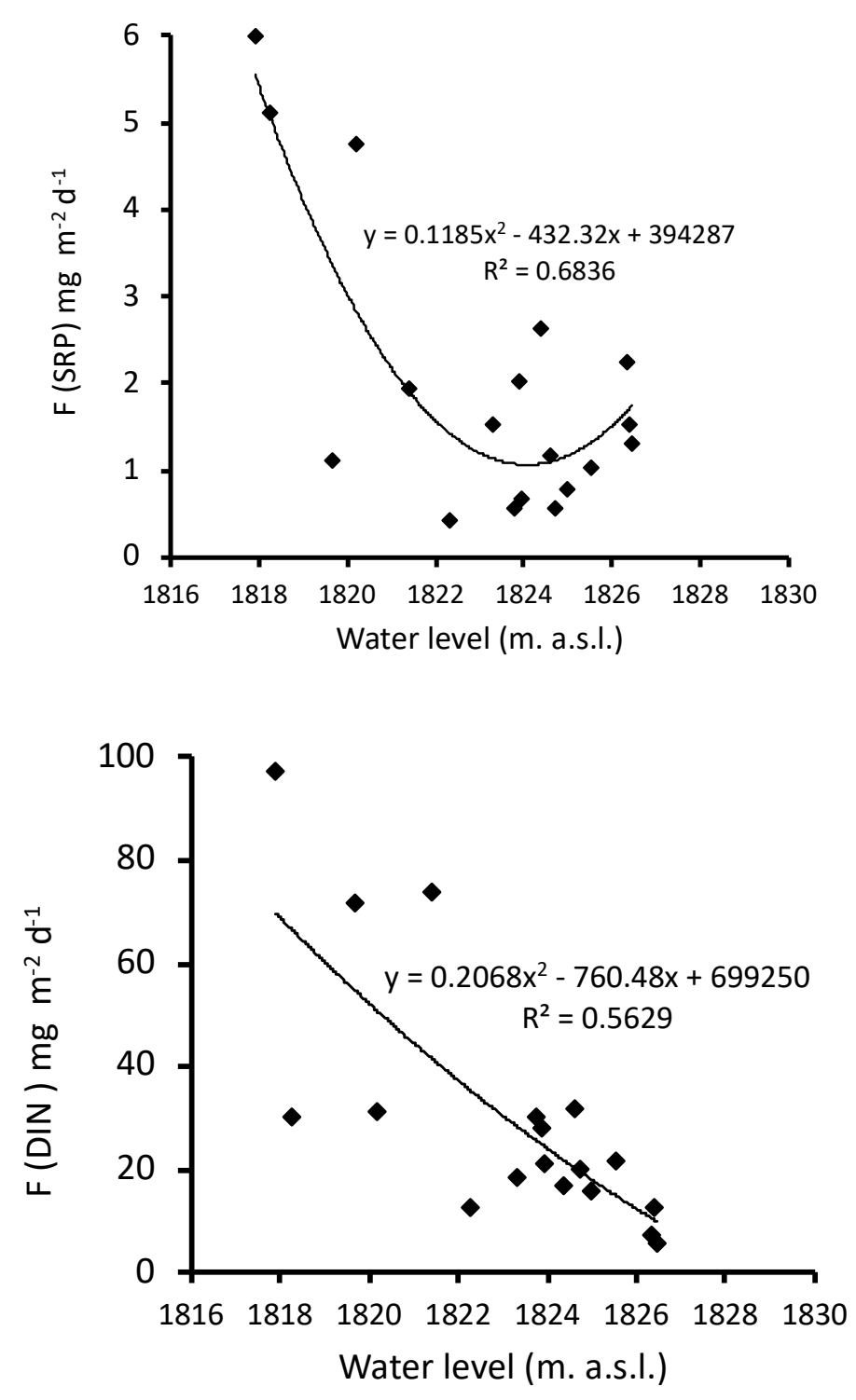

Figure 6. Mean rates of nutrient vertical flux (F) of: a) SRP and b) DIN, plotted against the annual mean water level of VB.

\section{Discussion}

The access of nutrients into the photic zone has major implications for the primary production and trophic webs of water bodies. This is largely controlled by physical factors that include the wind regime and water level fluctuations. The approach here presented derived from long-term observation throughout two decades of monthly monitoring at VB, where strong winds, eutrophication, and water extraction for Mexico City interplay in a system where explosive phytoplankton blooms are frequent [11,17]. In such a complex system, the assessment of the vertical exchange of water and nutrients and its variations can help to reveal the mixing and nutrient environment that plankton perceives. From this understanding, insight and prediction of the processes involved could be derived, and eventually become useful tools for the management of this and similar lakes and reservoirs in the global change scenarios to come. 
Despite of the major WLF recorded in VB during this 18 years, our observations demonstrated that this tropical lake behaves regularly as a monomictic tropical lake, exhibiting a stable stratification summer period and a circulation period during the winter $[10,11,14,15]$. Moderate seasonal changes in the water-level of VB occur every year as a function of seasonal rainfall variations in its basin, but higher WLF are a result of longerterm climatic variability and management decisions that consider requirements of water for human consumption and water availability within the Cutzamala water supply system as a whole, so they happen on multi-annual time scales. Therefore, a long-term series, as the one here reported, is required to include enough WLF variability to allow the identification of patterns and the effects of these variations in tropical deep lakes, like VB. The magnitude of WLF in VB during this period was so high that a level decrease of up to 12 $\mathrm{m}$ was registered, which is more than half of the mean depth of the lake when it is at its maximum level. It is remarkable that, nevertheless, VB remained stratified during the warm months (March to November) of each and all of the years (2001-2018) comprised in our sampling period.

Our results also showed that the hypolimnion warmed steadily during every stratification in VB throughout the entire observation period, although the warming rate varied from year to year. We attribute this warming to vertical mixing events, that are likely driven by internal waves caused by the wind pattern in VB, which has a very regular diurnal oscillation[11]. This is in agreement with the findings of [6,22-24] in similar systems, where internal waves have been proposed to drive boundary mixing and generate vertical nutrient transport.

In the absence of other heat sources than vertical mixing in VB, we have used the hypolimnetic warming rates to assess vertical mixing in VB during the stratification periods. Table 2 shows that our calculated coefficients $\left(4.0 \times 10^{-8} \mathrm{~m}^{2} \mathrm{~s}^{-1}\right.$ to $\left.1.2 \times 10^{-5} \mathrm{~m}^{2} \mathrm{~s}^{-1}\right)$ are amidst the range of values reported in specific studies of vertical diffusivity $\left(10^{-8} \mathrm{~m}^{2} \mathrm{~s}^{-1}\right.$ to $10^{-3} \mathrm{~m}^{2} \mathrm{~s}^{-1}$, Table 2), and rather on the lower part of the range. Both in tropical (e.g. Lake Lanao [28] in the Philippines and Kranji Reservoir [29] in Singapore) and in temperate (e.g. Lake Constance [33] in the border between Germany and Switzerland) systems, higher average $\mathrm{Kz}$ have been reported. In particular, at the intensely studied Lake Kinneret, where internal waves and boundary mixing are known to drive vertical mixing [31], measured vertical diffusivities are on the average about an order of magnitude higher that our mean of monthly $\mathrm{Kz}$ estimates.

Nevertheless, our monthly integrated vertical diffusivity values are, on average, comparable and slightly higher than those reported for other tropical lakes, including Lake Valencia [34] in Venezuela, Lake McIlaine [35] in Rhodesia and Lake Matano [36] in Indonesia, and are also higher that those found in some temperate lakes, such as Mono Lake [6,37] and Castle Lake [39] in California and Lake Alpnach [38] in Switzerland. Like we found here, $\mathrm{Kz}$ values have been found to vary around three orders of magnitude within the metalimnetic layer [44].

When comparing with other vertical diffusivity reports, it should be born in mind that our estimates assessed the effect of vertical mixing events averaged over a full month -i.e. between two consecutive sampling dates- while direct diffusivity measurements (such as most of those pooled together in Table 2) are done on much smaller time scales, and likely register the peak values that occur during mixing events. In contrast, our estimates are smoothed values over the full period between samplings, and are likely more representative of the long-term mixing rates. For instance, at Lake Kinneret, where mixing processes are amongst the most well-known, a study [31] outlines the variability that might affect the representativity of short term measurements: "most of the time the vertical flux through the metalimnion was negligible, but, at times, the eddy diffusivity did reach values as high as $10^{-2} \mathrm{~m}^{2} \mathrm{~s}^{-1}$ ". We believe that, by integrating the effect of these relevant vertical mixing pulses, our results likely better represent actual mixing rates at the near monthly scale. Nevertheless, to fully verify this in upcoming research we will be exploring the mixing intensity at short-time scales. 
In terms of their importance for $\mathrm{VB}$, the magnitude of the vertical water exchange rates here calculated (Table 1) imply that $5-11 \%$ of the total volume of the lake is being exchanged monthly between layers during the stratification period of the years when the water level is relatively high. But during the lowest water level years, this vertical exchange can reach up to $26 \%$ (e.g. 2009) of the lake's volume in a single month. When integrated for the full stratification periods, these volumes of water represent $40-83 \%$ of the total lake's volume being exchanged between layers, and this exchange can reach up to $131 \%$ of the lake's volume in the lower level and stronger mixing years, as in 2009 . These magnitudes suggest that vertical transport can be much higher than what would be expected from the traditional paradigm of stratification and metalimnetic barrier [2], and could also provide a physical mechanism to explain the sustained heterotrophic behavior (e.g., sustained high respiration rates) found for VB even under stratification conditions [14].

A cascade of ecosystemic processes are potentially affected by boundary mixing and vertical nutrient transport, as has been addressed broadly in the literature [45-50]. Understanding the relationships between temperature and vertical transport is key to model emergent ecosystem functions in a warmer world [18]. Previous reports of oxygen dynamics in VB and plankton community composition have been correlated with WLF and boundary mixing, and comprise indirect evidence consistent with the nutrient transport results presented here. In more detail, the observation of ephemeral patches of oxygen in the typically anoxic summer-autumn hypolimnion of VB [13], also supports the occurrence of frequent ( $\approx$ daily) events of boundary mixing in stratification. Moreover, low water periods were also correlated with higher respiration rates in VB in a 10 year-time series[14], pushing the metabolic balance to ecosystemic heterotrophy.

Boundary mixing events in the summer stratified period have been also correlated with important impacts in the plankton communities, for example with a diversification and biomass increase of the zooplankton community [13]. In particular, cladocerans and copepods have been observed to increase their abundance during low water level periods [13]. This is notorious because rotifers are normally the most prevalent zooplankton group in VB [51]. Additionally, the enhancement of phytoplankton biomass has also been reported during a low water level stratification compared to the same period in a year of high water level conditions [17]. This is consistent with -and would be expected to occur as a result of- the intensification of nutrient inputs to the epilimnion through boundary mixing here predicted. Furthermore, important changes in phytoplankton groups were also observed in the same study, where low water levels were characterized by increasing biomass of planktonic diatoms and a significant decrease of cyanobacteria (Nostocales).

When compared to other reports, our estimates of vertical nutrient fluxes of SRP and ammonia in VB are similar to those that have been calculated for lakes (Table 3), such as Kivu [40], Mendota [3], McIlwaine [35] and Malawi [42], when the average for all the years in 2001-2018 period are considered, including both lower and higher level years. However, the vertical nutrient fluxes for the stratification of the year (2009) with the lowest water level in VB would be higher than all those in Table 3, with the only exception of Lake Delavan in Wisconsin, where a flux as high as 15.2 of $\mathrm{mg} \mathrm{m}^{-2} \mathrm{~d}^{-1}$ was estimated by [30]. Our results clearly show that the vertical nutrient flux from the hypolimnion can increase in VB by an order of magnitude when the water-level drops sharply $(\approx 12 \mathrm{~m})$, a factor which has not been considered an important factor in water reservoir management until now.

When compared with the mean external phosphorus load to VB $\left(16.9 \pm 8.7 \mathrm{mg} \mathrm{TP} \mathrm{m}^{-2}\right.$ $\left.\mathrm{d}^{-1},[15]\right)$, nutrient vertical entrainment to the euphotic zone represents, on average, about $12 \%$ of the phosphorus annually entering the reservoir through its main tributaries. Nevertheless, this proportion can increase up to $>35 \%$ when the level decreases $12 \mathrm{~m}$ or more. Thus, the water level can alter significantly the amount of nutrients available in the euphotic zone of the lake during stratification, and therefore its primary production and functional eutrophication level, as identified by [14]. This is consistent with the fact that 
VB is more productive during stratification than during the circulation period $[13,14,17]$, during which nutrients would not be segregated to the hypolimnion. This could favor a more intensive recycling of nutrients in VB when the water level is low, while $\mathrm{N}$ and $\mathrm{P}$ fluxes to the sediments through sedimentation would likely be higher when the water level is high and vertical transport decreases. Furthermore, the changes in metabolism found in VB [13] associated to the variation of vertical mixing, have been found to alter both the metabolic balance and the role of the lake as a source or sink of carbon to the atmosphere [14], and all this would depend largely on the variation of WLF. As observed before, changes in water level and therefore mixing events can also drive changes in the planktonic composition, both for phytoplankton [17,50] and for zooplankton [51]. In particular, increased mixing can favor diatoms and decrease cyanobacterial blooms [17]. In $\mathrm{VB}$, the associated changes in zooplankton composition could favor fisheries availability [13]. Finally, there are also important effects of WLF on littoral communities [9], which are still to be studied in VB.

Altogether, the multiple consequences of WLF in windy tropical lakes such as VB can alter both the ecology of the lake and its suitability for a sustained water exploitation by the main users. The effects we have here identified should be accounted for by water managers [18], who could outweigh them against the particular needs of water distribution that may require affecting the water level of reservoirs and lakes.

\section{Conclusions}

The monomictic lake of VB exhibited hypolimnetic warming during the eighteen consecutive stratification periods of 2001-2018. Vertical mixing calculated from this warming through a heat balance showed there is a significant vertical exchange in this lake during the stratification months, which is comparable to the vertical diffusivity found for other tropical and temperate water bodies. The intensity of the vertical mixing in VB increases as the level of the lake decreases, likely because of the enhancement of boundary mixing events as internal waves intensify their interaction with the lake's bottom and margins, as found for other lakes that have a similar wind forcing. Vertical diffusivity coefficients calculated for VB are within the range found in this kind of lakes but are comparatively low, likely because they integrate the average vertical mixing occurring over monthly to annual scales, while most direct measurements reported for other water bodies address peak mixing pulses.

The vertical nutrient transport derived from this water exchange in VB would be enough to overcome the stratification barrier and sustain the observed eutrophic conditions during stratification. This is consistent with the fact that VB is more productive during stratification than during the circulation period, during which nutrients would not be segregated to the hypolimnion. The estimated vertical nutrient entrainment to the epilimnion in VB is on average similar to that reported for other systems, but seems to become much higher during years with low water levels. These vertical mixing and associated nutrient flux affect significantly the planktonic communities, the metabolic balance of the lake, and likely the recycling of the external nutrient loading to the lake and the fraction that may be accumulated at the bottom of VB.

Our model provides insight into the physical controllers of the trophic status of water bodies, in particular windy tropical lakes with high water-level fluctuations. It allows for the prediction of vertical mixing and nutrient entrainment as a function of the water level in the lake, providing an additional tool for water authorities and lake users to improve their management strategies of this and similar lakes.

Author Contributions: For research articles with several authors, a short paragraph specifying their individual contributions must be provided. The following statements should be used "Conceptualization, M.M-I.; methodology, M.M-I., E.M-R., J.A.R-Z. and F.S.C-S.; validation, M.M-I. and S.S-C.; formal analysis, J.A.R-Z..; investigation, all authors participated in the data collection.; resources 
and data curation, F.S.C-S.; writing-original draft preparation, M.M-I., J.A.R-Z. and P.M.V-C.; writing-review and editing, M.M-I. and M.B.-A.; visualization, J.A.R-Z.; supervision, S.S-C.; project administration and funding acquisition, M.M-I. All authors have read and agreed to the published version of the manuscript.

Funding: This research was funded by UNAM, PAPIIT-IN207702 and CONACYT-SEMARNAT, C01-1125 projects to M.M-I.

Acknowledgments: We thank Provalle A.C., Marina Azul, and Naútico Avandaro Sailing Clubs for their support of this research with boats and docking facilities. We also thank all the Aquatic Biogeochemistry Lab collaborators, including, Lourdes N. Murueta, Flor Arcega, Irina Cruz, Sofía Montalvo, Rebeca Sánchez, Claudia N. Saavedra, Patricia Memije, Alfredo Gallardo, Felipe Solís, Federico Serna Blanco, Arturo Alvarez, Felipe Solis, Mónica Olson, Karina Castro, Abraham Vargas. We also acknowledge the stimulating support from VB lovers, particularly Alberto Dana, Esther Carrillo, Daniel Coranguez and Tito Benítez.

Conflicts of Interest: The authors declare no conflict of interest. The funders had no role in the design of the study; in the collection, analyses, or interpretation of data; in the writing of the manuscript, or in the decision to publish the results.

\section{References}

1. Imberger, J. Flux paths in a stratified lake: A review. In Physical Processes in Lakes and Oceans; Coastal and Estuarine Studies; 1998; pp. $1-17$.

2. Kalff, J. Limnology: inland water ecosystems.; 2002; ISBN 0130337757.

3. Kamarainen, A.M.; Penczykowski, R.M.; Van de Bogert, M.C.; Hanson, P.C.; Carpenter, S.R. Phosphorus sources and demand during summer in a eutrophic lake. Aquat. Sci. 2009, 71, 214-227, doi:10.1007/s00027-009-9165-7.

4. Lean, D.R.S.; Abbott, A.A.; Pick, F.R. Phosphorus deficiency of Lake Ontario plankton. Can. J. Fish. Aquat. Sci. 1987, 44, 2069-2076, doi:10.1139/f87-256.

5. Staehr, P.A.; Sand-Jensen, K. Temporal dynamics and regulation of lake metabolism. Limnol. Oceanogr. 2007, 52, 108-120, doi:10.4319/10.2007.52.1.0108.

6. MacIntyre, S.; Flynn, K.M.; Jellison, R.; Romero, J.R. Boundary mixing and nutrient fluxes in Mono Lake, California. Limnol. Oceanogr. 1999, 44, 512-529, doi:10.4319/10.1999.44.3.0512.

7. MacIntyre, S.; Jellison, R. Nutrient fluxes from upwelling and enhanced turbulence at the top of the pycnocline in Mono Lake, California. Hydrobiologia 2001, 466, 13-29, doi:10.1023/A:1014563914112.

8. Auger, G.; Yamazaki, H.; Nagai, T.; Jiao, C.; Kumagai, M. Hypolimnetic turbulence generation associated with superposition of largescale internal waves in a strongly stratified lake: Lake Biwa, Japan. Limnology 2013, 14, 229-238, doi:10.1007/s10201-013-0401-4.

9. Zohary, T.; Ostrovsky, I. Ecological impacts of excessive water level fluctuations in stratified freshwater lakes. Inl. Waters 2011, 1, 4759, doi:10.5268/IW-1.1.406.

10. Valdespino-Castillo, P.M.; Merino-Ibarra, M.; Ramírez-Zierold, J.A.; Castillo, F.S.; González-de-Zayas, R.; Carnero-Bravo, V. Hacia el inventario de flujos de carbono en aguas tropicales: unificar métodos. Tecnol. y ciencias del agua 2019, 10, 234-252, doi:10.24850/jtyca-2019-01-09.

11. Merino-Ibarra, M.; Monroy-Ríos, E.; Vilaclara, G.; Castillo, F.S.; Gallegos, M.E.; Ramírez-Zierold, J. Physical and chemical limnology of a wind-swept tropical highland reservoir. Aquat. Ecol. 2008, 42, 335-345, doi:10.1007/s10452-007-9111-5.

12. Merino, M.; Monroy, E.; Castillo, S.; Ramírez, J.; Gallegos, M.E.; Alcocer, J. Wind-driven upwelling indicated by hydrological variability in a tropical eutrophied reservoir, Valle de Bravo, Mexico. In Proceedings of the 4th International Conference on Reservoir Limnology and Water Quality; 2003; pp. 228-231.

13. Valdespino-Castillo, P.M.; Merino-Ibarra, M.; Jiménez-Contreras, J.; Castillo-Sandoval, F.S.; Ramírez-Zierold, J.A. Community metabolism in a deep (stratified) tropical reservoir during a period of high water-level fluctuations. Environ. Monit. Assess. 2014, 186, 6505-6520, doi:10.1007/s10661-014-3870-y. 
14. Guimarais-Bermejo, M.O.; Merino-Ibarra, M.; Valdespino-Castillo, P.M.; Castillo-Sandoval, F.S.; Ramírez-Zierold, J.A. Metabolism in a deep hypertrophic aquatic ecosystem with high water-level fluctuations: A decade of records confirms sustained net heterotrophy. PeerJ 2018, 2018, doi:10.7717/peerj.5205.

15. Ramírez-Zierold, J.A.; Merino-Ibarra, M.; Monroy-Ríos, E.; Olson, M.; Castillo, F.S.; Gallegos, M.E.; Vilaclara, G. Changing water, phosphorus and nitrogen budgets for Valle de Bravo reservoir, water supply for Mexico City Metropolitan Area. Lake Reserv. Manag. 2010, 26, 23-34, doi:10.1080/07438140903539790.

16. Fadel, A.; Lemaire, B.J.; Vinçon-Leite, B.; Atoui, A.; Slim, K.; Tassin, B. On the successful use of a simplified model to simulate the succession of toxic cyanobacteria in a hypereutrophic reservoir with a highly fluctuating water level. Environ. Sci. Pollut. Res. 2017, 24, 20934-20948, doi:10.1007/s11356-017-9723-9.

17. Valeriano-Riveros, M.E.; Vilaclara, G.; Castillo-Sandoval, F.S.; Merino-Ibarra, M. Phytoplankton composition changes during water level fluctuations in a high-altitude, tropical reservoir. Inl. Waters 2014, 4, 337-348, doi:10.5268/IW-4.3.598.

18. May, L.; Aura, C.M.; Becker, V.; Briddon, C.L.; Carvalho, L.R.; Dobel, A.J.; Jamwal, P.; Kamphuis, B.; Marinho, M.M.; McGowan, S.; et al. Getting into hot water: Water quality in tropical lakes in relation to their utilisation. IOP Conf. Ser. Earth Environ. Sci. 2021, 789, 012021, doi:10.1088/1755-1315/789/1/012021.

19. Alcocer, J.; Lugo, A.; Escobar, E.; Sànchez, M.R.; Vilaclara, G. Water column stratification and its implications in the tropical warm monomictic Lake Alchichica, Puebla, Mexico. SIL Proceedings, 1922-2010 2000, 27, 3166-3169, doi:10.1080/03680770.1998.11898262.

20. Nandini, S.; Merino-Ibarra, M.; Sarma, S.S.S. Seasonal changes in the zooplankton abundances of the reservoir Valle de Bravo (State of Mexico, Mexico). Lake Reserv. Manag. 2008, 24, 321-330, doi:10.1080/07438140809354842.

21. Kirkwood, D.S. Sanplus segmented flow analyzer and its applications. Seawater analysis. Skalar. Amsterdam 1994.

22. Thorpe, S.A. Statically unstable layers produced by overturning internal gravity waves. J. Fluid Mech. 1994, 260, 333-350, doi:10.1017/S002211209400354X.

23. MacIntyre, S.; Melack, J.M. Vertical and Horizontal Transport in Lakes: Linking Littoral, Benthic, and Pelagic Habitats. J. North Am. Benthol. Soc. 1995, 14, 599-615, doi:10.2307/1467544.

24. Ostrovsky, I.; Yacobi, Y.Z.; Walline, P.; Kalikhman, I. Seiche-induced mixing: Its impact on lake productivity. Limnol. Oceanogr. 1996, 41, 323-332, doi:https://doi.org/10.4319/1o.1996.41.2.0323.

25. IDSO, S.B. On the concept of lake stability. Limnol. Oceanogr. 1973, 18, 681-683, doi:10.4319/1o.1973.18.4.0681.

26. MacIntyre, S. Vertical mixing in a shallow, eutrophic lake: Possible consequences for the light climate of phytoplankton. Limnol. Oceanogr. 1993, 38, 798-817, doi:https://doi.org/10.4319/lo.1993.38.4.0798.

27. Brookes, J. Effects of diurnal vertical mixing and stratification on phytoplankton productivity in geothermal Lake Rotowhero, New Zealand. Inl. Waters 2013, 3, 369-376, doi:10.5268/IW-3.3.625.

28. Lewis, W.M. Vertical eddy diffusivities in a large tropical lake1. Limnol. Oceanogr. 1982, 27, 161-163, doi:10.4319/10.1982.27.1.0161.

29. Yang, P.; Fong, D.A.; Lo, E.Y.-M.; Monismith, S.G. Vertical mixing in a shallow tropical reservoir. Limnology 2019, 20, 279-296, doi:10.1007/s10201-019-00577-z.

30. Stauffer, R.E. Vertical nutrient transport and its effects on epilimnetic phosphorus in four calcareous lakes. Hydrobiologia 1987, 154, 87-102, doi:10.1007/BF00026833.

31. Saggio, A.; Imberger, J. Mixing and turbulent fluxes in the metalimnion of a stratified lake. Limnol. Oceanogr. 2001, 46, 392-409, doi:10.4319/10.2001.46.2.0392.

32. Bormans, M.; Ford, P.W.; Fabbro, L.; Hancock, G. Onset and persistence of cyanobacterial blooms in a large impounded tropical river, Australia. Mar. Freshw. Res. 2004, 55, 1, doi:10.1071/MF03045.

33. Preusse, M.; Peeters, F.; Lorke, A. Internal waves and the generation of turbulence in the thermocline of a large lake. Limnol. 
Oceanogr. 2010, 55, 2353-2365, doi:https://doi.org/10.4319/lo.2010.55.6.2353.

34. Lewis, W.M. Temperature, heat, and mixing in Lake Valencia, Venezuela1. Limnol. Oceanogr. 1983, 28, 273-286, doi:10.4319/10.1983.28.2.0273.

35. Robarts, R.D.; Ward, P.R.B. Vertical diffusion and nutrient transport in a tropical lake (Lake McIlwaine, Rhodesia). Hydrobiologia 1978, 59, 213-221, doi:10.1007/BF00036500.

36. Katsev, S.; Crowe, S.A.; Mucci, A.; Sundby, B.; Nomosatryo, S.; Douglas Haffner, G.; Fowle, D.A. Mixing and its effects on biogeochemistry in the persistently stratified, deep, tropical Lake Matano, Indonesia. Limnol. Oceanogr. 2010, 55, 763-776, doi:10.4319/10.2010.55.2.0763.

37. Jellison, R.; Melack, J.M. Meromixis in hypersaline Mono Lake, California. 1. Stratification and vertical mixing during the onset, persistence, and breakdown of meromixis. Limnol. Oceanogr. 1993, 38, 1008-1019, doi:10.4319/1o.1993.38.5.1008.

38. Goudsmit, G.-H.; Peeters, F.; Gloor, M.; Wüest, A. Boundary versus internal diapycnal mixing in stratified natural waters. J. Geophys. Res. Ocean. 1997, 102, 27903-27914, doi:https://doi.org/10.1029/97JC01861.

39. Jassby, A.; Powell, T. Vertical patterns of eddy diffusion during stratification in Castle Lake, California1. Limnol. Oceanogr. 1975, 20, 530-543, doi:10.4319/10.1975.20.4.0530.

40. Pasche, N.; Dinkel, C.; Mu\#x00FC;ller, B.; Schmid, M.; est, A.W.; Wehrlia, B. Physical and biogeochemical limits to internal nutrient loading of meromictic Lake Kivu. Limnol. Oceanogr. 2009, 54, 1863-1873, doi:https://doi.org/10.4319/lo.2009.54.6.1863.

41. Kamarainen, A.M.; Yuan, H.; Wu, C.H.; Carpenter, S.R. Estimates of phosphorus entrainment in Lake Mendota: a comparison of onedimensional and three-dimensional approaches. Limnol. Oceanogr. Methods 2009, 7, 553-567, doi:10.4319/lom.2009.7.553.

42. Hamblin, P.F.; Bootsma, H.A.; Hecky, R.E. Modeling Nutrient Upwelling in Lake Malawi/Nyasa. J. Great Lakes Res. 2003, 29, 34-47, doi:https://doi.org/10.1016/S0380-1330(03)70537-1.

43. Edwards, R.L.; Priscu, J.C. McMurdo LTER: Relationships between vertical nutrient flux and phytoplankton biomass and productivity in lakes of the Taylor Valley, Antarctica. Antarct. J. U.S. 1995, 30.

44. Lin, S.; Boegman, L.; Rao, Y.R. Characterizing spatial and temporal distributions of turbulent mixing and dissipation in Lake Erie. $J$. Great Lakes Res. 2021, 47, 168-179, doi:10.1016/j.jglr.2020.11.014.

45. Pomati, F.; Matthews, B.; Jokela, J.; Schildknecht, A.; Ibelings, B.W. Effects of re-oligotrophication and climate warming on plankton richness and community stability in a deep mesotrophic lake. Oikos 2012, 121, 1317-1327, doi:10.1111/j.1600-0706.2011.20055.x.

46. Matzinger, A.; Schmid, M.; Veljanoska-Sarafiloska, E.; Patceva, S.; Guseska, D.; Wagner, B.; Müller, B.; Sturm, M.; Wüest, A. Eutrophication of ancient Lake Ohrid: Global warming amplifies detrimental effects of increased nutrient inputs. Limnol. Oceanogr. 2007, 52, 338-353, doi:10.4319/10.2007.52.1.0338.

47. Rabalais, N.N.; Turner, R.E.; Díaz, R.J.; Justić, D. Global change and eutrophication of coastal waters. ICES J. Mar. Sci. 2009, 66, 1528-1537, doi:10.1093/icesjms/fsp047.

48. Boyce, D.G.; Lewis, M.R.; Worm, B. Global phytoplankton decline over the past century. Nature 2010, 466, 591-596, doi:10.1038/nature09268.

49. Bartosiewicz, M.; Przytulska, A.; Deshpande, B.N.; Antoniades, D.; Cortes, A.; MacIntyre, S.; Lehmann, M.F.; Laurion, I. Effects of climate change and episodic heat events on cyanobacteria in a eutrophic polymictic lake. Sci. Total Environ. 2019, 693, 133414, doi:10.1016/j.scitotenv.2019.07.220.

50. Xu, H.; Yan, M.; Long, L.; Ma, J.; Ji, D.; Liu, D.; Yang, Z. Modeling the Effects of Hydrodynamics on Thermal Stratification and Algal Blooms in the Xiangxi Bay of Three Gorges Reservoir. Front. Ecol. Evol. 2021, 8, 453, doi:10.3389/fevo.2020.610622.

51. Contreras, J.J.; Sarma, S.S.S.; Merino-Ibarra, M.; Nandini, S. Seasonal changes in the rotifer (Rotifera) diversity from a tropical high altitude reservoir (Valle de Bravo, Mexico). J. Environ. Biol. 2009, 30, 191-195. 